\title{
Courts, Contracts, and the Appropriate Discount Rate: A Quick Fix for the Legal Lottery
}

\author{
Christopher P. Bowers $\dagger$
}

Although courts have long recognized that "[u]ncertainty and ambiguity are the bane of commerce," they often fail to practice what they preach. In an era of increasingly complex transactions and big-money deals, the legal system subjects sophisticated commercial parties to ambiguous standards and uncertain damage awards. ${ }^{2}$ One businessman, tired of the vagaries of the system, aptly described going to court as a "legal lottery where you don't know whether you will win; and if you win, you may be either under or overcompensated."3

When courts select discount rates for measuring lost future profits in commercial-contract disputes, this uncertainty is especially troubling. Discounting is the process by which courts take into account the time value of money to avoid overcompensating the injured party. ${ }^{4}$ The process is relatively straightforward, requiring the court to find an interest rate at which an injured

$\dagger$ B.A. 1994, Fordham College; J.D. Candidate 1997, The University of Chicago.

${ }^{1}$ Merritt $v$ Welsh, 104 US 694, 702 (1881).

2 See, for example, Edward Felsenthal, Increase in Size of Jury Awards May Spur Efforts to Alter System, Wall St J B2, B2 (Jan 5, 1996) (explaining that the size of jury awards increased for the second year in a row and that this data may help spur an overhaul of the civil justice system); Oki America, Inc. $v$ Microtech International, Inc., 872 F2d 312, 315 (9th Cir 1989) (Kozinski concurring) (commenting that the California tort of bad faith denial of contract "generates serious costs and uncertainties, trivializes the law and denies individuals and businesses the autonomy of adjusting mutual rights and responsibilities through voluntary contract").

3 David Baumer and Patricia Marschall, Willful Breach of Contract for the Sale of Goods: Can the Bane of Business Be an Economic Bonanza?, 65 Temple L Rev 159, 166 (1992) (analyzing the results of a survey presenting the business community's reaction to deliberate breach).

- See, for example, Dan B. Dobbs, 2 Law of Remedies $\S 8.5$ (3) at 469 (West 2d ed 1993) ("[Present value's] aim is to find and award a sum of money which, when invested safely, will suffice to pay all the future damages as they occur by using both the award itself and the interest it earns."). See also Roger D. Blair, Measuring Damages for Lost Profits in Franchise Termination Cases, 8 Franchise L J 3, 4 (Fall 1988) ("Generally, the plaintiff wants a lump-sum award that is economically equivalent to what has been lost.... In other words, the plaintiff wants a lump-sum payment that can be invested today to yield a stream of payments in the future that will replace the profit stream."). 
party can invest the damage fund. But the court must choose the proper rate to get the right result. ${ }^{5}$ Indeed, a difference of 1 percent or less in the discount rate used in the present value calculations can result in millions of dollars lost or gained in a damage award. ${ }^{6}$

The case law concerning the selection of appropriate discount rates for measuring lost future profits in contract disputes is in disarray. Discount-rate selection requires a finding of fact; thus, the choice of the appropriate discount rate is left to the wisdom of the fact finder. In practice, juries have produced inconsistent results, and judges have found in favor of rates based on vague "fair and reasonable" rationales. ${ }^{7}$ Discretion thus prevails in contract discount-rate determinations-decisions that are even more complicated than the discounting of lost future wages in tort adjudications, where courts simply choose an interest rate that would be earned on "the best and safest investments."

5 See Manfred H. Ledford and Dennis P. Zocco, New Evidence on the Selection of an Appropriate Discount Rate in Economic Loss Determinations, 36 Fed'n Ins \& Corp Couns $Q 27,39$ (1985) (" $[T]$ he choice of a discount rate to be used in the determination of the present value equivalent of a stream of economic losses is extremely critical."); Blair, 8 Franchise $L J$ at 6, 23 (cited in note 4) ("In order to calculate correctly the present value of the lost profits, one must select the correct discount rate from a considerable number of alternatives.").

${ }_{6}$ For a discussion of how differences in discount rates affect damage awards, see text accompanying notes 25-28.

7 See Section I.B.

8 Chesapeake \& Ohio Railway Co. $v$ Kelly, 241 US 485, 491 (1916). Tort commentators have wrestled with trying to implement this standard for decades. For a representative sampling of such articles, see note 57.

The tort commentary offers only tangential assistance to a court adjudicating a commercial-contract dispute for three reasons. First, the tort commentary focuses on an individual's lost earnings and not on a corporation's lost profits. A corporation is assumed to have greater financial expertise and should not be held to the same (lower) standard of investment acumen as the individual. See text accompanying notes 126-34.

Second, the methodologies for calculating rates of return vary in the tort and commercial-contract contexts. Experts employ an array of financial theories to calculate potential rates of return for corporations, but most of the tort commentary focuses on only one theory: the risk-free rate of return for individuals. See generally Gary A. Anderson and David L. Roberts, Economic Theory and the Present Value of Future Lost Earnings: An Integration, Unification, and Simplification of Court Adopted Methodologies, 39 U Miami L Rev 723 (1985); Frank Slesnick, Can a Court Effectively Determine Discount Rates: An Economic Perspective, 14 U Dayton L Rev 81 (1988).

Finally, commercial-contract law is a body of clear default rules around which parties can bargain. Tort law, however, generally deals with involuntary exchanges and typically does not contemplate parties bargaining around default rules before the fact. Thus the tort commentary is at best an imperfect guide for courts seeking the most appropriate default rule in a commercial-contract dispute.

The tort commentary does, however, provide useful and pertinent discussions about the perils of discounting in general and is thus applicable in this limited respect. Indeed, 
Commercial parties are left to struggle with the uncertainty of random results and rulings without rationales.

Experts, rather than helping fact finders do their job, have merely compounded the confusion and aggravated the variability of the results. As the world of finance has become more sophisticated, parties have eagerly introduced financial experts to testify as to appropriate discount rates and to impress fact finders. Financial analysis, however, offers a smorgasbord of approaches to computing a business's expected return on investments, and each approach yields different results. Moreover, expensive experts can manipulate assumptions and data to generate disparate results even within the same theory. Finally, expert commentators write mainly for other experts and have failed to bridge the gap between the world of law and the world of finance. ${ }^{9}$ This battle of the experts does little more than add confusion and cost to an already chaotic regime.

A discretionary regime, marked by uncertainty and expense, presently determines the appropriate discount rate. Such a regime encourages parties to use experts because fact finders defer to them. If one party presents an expert, the other party may be at a disadvantage if it fails to present its own. ${ }^{10}$ Businesses thus truly engage in a perverse lottery in which parties pay a great deal for small or nonexistent benefits.

This Comment argues that courts should dismantle the discretionary discount rate and thereby eliminate many of the costs and uncertainties of the legal lottery. It proposes that courts adopt an easily identifiable, fixed market peg, such as the Dow Jones Industrial Average, a corporate-bond index, or the Treasury bill rate, when discounting lost future profits in breachof-contract cases. ${ }^{11}$ By fixing the discount rate to such a market

some of these articles provide good reference points for implementing contract-law innovations. See note 136.

$\theta$ In fact, one economist has claimed that financial experts have failed to fill gaps even within the world of finance. See W. Cris Lewis, The Role of the Discount and Reinvestment Rate in Calculating Future Economic Loss, 34 Fed'n Ins Couns Q 223, 223 (1984) ('In my opinion, some 'experts' regularly use discount rates without fully understanding the implications of the discounting process. The use of significantly different rates by experts in the same or similar cases goes beyond mere disagreement about the level of interest rates in the future.").

${ }^{10}$ See Douglas G. Baird, Robert H. Gertner, and Randal C. Picker, Game Theory and the Law 64 (Harvard 1994) ("Litigation is like a contest because the chances of success turn in some measure on which party spends the most. Once one party spends money on litigation, the other party has an incentive to respond by spending a little bit more.").

11 Pegging the discount rate to a financial index does not fix the rate for all time. Market indices, such as the Dow Jones Industrial Average, are merely composites of 
peg on the day of the breach, neither judge, jury, nor expert determines the discount rate. Rather, the natural ebb and flow of financial markets will do the job. The resulting benefits of increased certainty and lower decision costs should justify abandoning the misguided search for the "right" rate.

Section I illustrates the mechanics of discounting in lostprofit disputes. It also highlights the importance of choosing the proper discount rate and examines how fact finders have failed to perform this vital task. Section II analyzes five approaches that expert practitioners may employ to calculate appropriate discount rates and explains how each of these approaches fails as a proper default rule for choosing discount rates in commercial-contract disputes. Finally, Section III proposes that courts break from the discretionary discount regime and select a rate based on a fixed market peg, preferably the medium-grade-corporate-bond rate. To support this argument, Section III employs a common sense, costbenefit analysis comparing the proposed fixed-rate rule to the discretionary regime now in place. The Comment concludes that the use of a fixed rate would eliminate many of the private and social costs of the current discretionary approach without causing unreasonable disruptions, thus increasing certainty and clarity to the benefit of commerce.

\section{Courts and Discount Rates}

Courts recognize that they must discount awards of lost future profits in contract disputes to avoid overcompensating the injured plaintiff. No standards, however, guide courts through the essential mechanics of discounting, especially the choice of the appropriate discount rate. Accordingly, such decisions are products of judicial discretion, and parties are often subject to unpredictable results based on uncertain rationales.

\section{A. Compensation and Contract Law: The Discount Solution}

1. The time value of money and the compensation principle.

Injured commercial parties often receive lump-sum damage awards to compensate them for lost future profits. ${ }^{12}$ Courts in- 
tend for this lump-sum award to replace money that the injured party would have earned over the remaining term of the broken contract. For example, a company that was supposed to earn $\$ 100,000$ a year in profits on a ten-year contract that fell apart on day one would argue for a cash award of $\$ 1$ million to compensate it for the profits that it would have made but for the breach.

If the injured company received this award undiscounted, however, it could immediately invest the cash and earn even more money than it would have earned under the contract. Money has time value: $\$ 1$ million, invested at an annual interest rate of 10 percent, earns $\$ 100,000$ of interest per year. ${ }^{13}$ The injured plaintiff could invest the undiscounted damage award, recoup its lost profits over the ten-year period, and still have $\$ 1$ million remaining in the bank after the original term of the contract expires.

A court adjudicating this case would be caught in a dilemma. Awarding the injured company the full million dollars now would certainly overcompensate the company because it could convert the cash into a greater stream of income than it expected under the contract. ${ }^{14}$ This would violate the principal goal of contract

of contract. See UCC $\S 2-708(2)$ (West 1989) ("[T]he measure of damages is the profit ... which the seller would have made from full performance ....").

${ }^{23}$ The expected growth of a principal amount due to interest compounding can be determined by calculating the principal amount's future value. The computation of future value is relatively straightforward. A given principal amount $P$ compounded annually at a given interest rate (i) for a given number of years $(t)$ will have a future value $(F V)$ at the end of that time given by the exponential function:

$$
F V=P(1+i)^{t}
$$

Thus, plugging in the values cited in the above example, we find that the future value of the damage award at the end of year one is:

$$
\begin{aligned}
\mathrm{FV} & =1,000,000(1+.10)^{1} \\
& =1,000,000(1.1) \\
& =1,100,000
\end{aligned}
$$

The plaintiff can then skim off the interest and keep the $\$ 1$ million safely invested, ready to earn another year of interest. For a basic introduction to the mechanics of finding future values, see Edward T. Dowling, Introduction to Mathematical Economics 176 (McGraw-Hill 2d ed 1992).

" See Gillanders v Gillanders, 49 Wash App 457, 743 P2d 1252, 1253-54 (1987), quoting Dan B. Dobbs, Law of Remedies 178 (West 1973) ("[A]n award for payments due in the future ... would overcompensate the plaintiff [for his damages], because it would give him the money not due him until later, which would allow him to have the money when due, plus all the interest he might earn on it."). 
damages: to give the plaintiff the benefit of his contract and no more. ${ }^{15}$ Both parties, however, want the "clean break" of a lumpsum award in order to avoid the costly future dealings that a stream of damage payments would entail. How then can a court satisfy both parties without overcompensating the injured one?

\section{The discount solution.}

Finance theory offers a solution to this compensation dilemma. If the plaintiff can invest an award that will grow to a certain sum in the future, why not start with the future value and work backwards to figure out the proper award today? In other words, the court should give the plaintiff an amount now such that, when invested, "the sum of the original award plus interest will just equal the anticipated loss." Accordingly, the court should award the present value of the future profits-the amount delivered today that will grow under current investment conditions to compensate the plaintiff in the future. ${ }^{17}$

Discounting is the process of determining the present value of a future sum of money. ${ }^{18}$ When finding present value, the dis-

${ }^{15}$ See Samuel Williston, 11 A Treatise on the Law of Contracts $\$ 1338$ at 198 (Baker, Voorhis 3d ed 1968) ("In fixing the amount of these damages, the general purpose of the law is, and should be, to give compensation, that is, to put the plaintiff in as good a position as he would have been in had the defendant kept his contract."). See also Hawkins $v$ McGee, $84 \mathrm{NH} 114,146$ A 641, 643 (1929) (quoting Williston).

${ }_{16}$ Roy F. Gilbert, Forensic Discount Rates, $4 \mathrm{~J}$ Legal Econ 40, 40 (Dec 1991). For additional discussion regarding the purposes of discounting and the need to achieve proper levels of compensation, see William F. Landsea and David L. Roberts, Inflation and the Present Value of Future Economic Damages, 37 U Miami L Rev 93, 95 (1982); Dobbs, 2 Law of Remedies $\$ 8.5(3)$ at 469 (cited in note 4).

${ }^{17}$ See Robert L. Dunn, Recovery of Damages for Lost Profits $\$ 6.12$ at 278 (Lawpress $2 d$ ed 1981) (stating that if an "award is to compensate for a loss of profits projected over ten years, the amount should be that which, if invested for ten years at appropriate (probably conservative) rates of return, will produce the amount of the loss").

${ }_{18}$ Present value is simply the inverse of future value. Using the formula in note 13, in which $P$ is the principal invested and FV is the future value expected, we derive the present value formula by solving for $P$ :

$$
\begin{aligned}
& F V=P(1+i)^{t} \\
& P=F V /(1+i)^{t} \\
& P=F V(1+i)^{-t}
\end{aligned}
$$

This formula tells us the present value of a particular sum received in the future. Under our $\$ 1$ million hypothetical, this formula can be used to discount the $\$ 100,000$ payment for each year of the contract to its present value. Thus, again assuming an interest rate of 10 percent, the present value of the $\$ 100,000$ to be paid after year one equals about $\$ 90,909$ :

$$
P=100,000(1+.10)^{-1}
$$


count rate is merely the interest rate or rate of return that the plaintiff expects his money to earn. ${ }^{19}$ Accordingly, assuming 10 percent as the proper discount rate, the present value of $\$ 100,000$ in profits per year for ten years is approximately $\$ 614,460 .^{20}$ The plaintiff can then invest this amount to offset the $\$ 100,000$ annual loss for the next ten years. By awarding the present value of the lost profits, a court will compensate the injured party neither too little nor too much.

\section{B. The Courts' Response: Confusion}

\section{Discounting and the appropriate discount rate.}

Courts generally accept the principle that "a dollar to-day is worth more than a dollar next year, and to ignore the interval as immaterial is to contradict well-settled beliefs about value."21 Indeed, in Chesapeake \& Ohio Railway Co. v Kelly, the Supreme Court commanded that "in all cases where it is reasonable to suppose that interest may safely be earned upon the amount that is awarded, the ascertained future benefits ought to be discounted in the making up of the award."22 Accordingly, from cases in

$$
\begin{gathered}
=100,000(.909091) \\
=90,909 \cdot 10
\end{gathered}
$$

The present value of $\$ 100,000$ to be paid after year two equals about $\$ 82,645$. The present values of $\$ 100,000$ to be paid after years three through ten can be calculated in a similar way. After the discounting process is complete, the discounted values are added together to find the total present value of this future stream of income.

Alternatively, one can use the following formula to discount future streams of income where, as in the above example, the FV is the same for each year and interest is compounded annually:

$$
P=S(1 / i)\left[1-(1+i)^{-t}\right]
$$

Here, $\mathbf{S}$ represents the annual stream of future income. This formula saves much time and effort, especially if the expected stream of profits is paid over many years. See Dowling, Mathematical Economics at 177-78 (cited in note 13).

19 Id at 177.

20 Plugging our numbers into the above formula we find:

$$
\begin{gathered}
P=(100,000 / .10)\left[1-(1.10)^{-10}\right] \\
=(1,000,000)(.6144567) \\
\cong 614,460
\end{gathered}
$$

Often these tedious calculations can be avoided through the use of present and future value tables found in most introductory financial accounting books. See, for example, Michael A. Diamond, Financial Accounting 901 (South-Western 3d ed 1993).

21 Proctor \& Gamble Distributing Co. $v$ Sherman, 2 F2d 165, 166 (S D NY 1924).

22241 US 485, 490 (1916). See also Monessen Southwestern Railway Co. v Morgan, 
bankruptcy and property to cases in tort and contract, ${ }^{23}$ most courts discount future streams of income to account for the time value of money and to award more finely tuned compensation. ${ }^{24}$

Proper discounting, however, requires the choice of a proper discount rate. In commercial contracts, where the stakes are high, a difference of 1 percent in the discount rate can have substantial effects on the damage award. ${ }^{25}$ For example, a decrease in the discount rate from 10 percent to 9 percent in our above example increases the plaintiff's damage award by over $\$ 27,000 .{ }^{26}$ Conversely, an increase in the discount rate from 10

486 US 330, 339-40 (1988) (finding that damage awards in federal law should be discounted to present value).

${ }_{23}^{23}$ See, for example, In re Monnier Brothers, 755 F2d 1336, 1337 (8th Cir 1985) (bankruptcy); Whitney Benefits, Inc. v United States, $18 \mathrm{Cl} \mathrm{Ct} \mathrm{394,} 399$ (1989) (property); O'Shea $v$ Riverway Towing Co., 677 F2d 1194, 1197 (7th Cir 1982) (tort); American List Corp v U.S. News and World Report, Inc., 75 NY2d 38, 550 NYS 2d 590, 592 (1989) (contract).

${ }^{24}$ Some jurisdictions, however, have expressly rejected the use of discounting, opting instead for a "total offset" rule. The total offset method recognizes that money has time value, but argues that inflation offsets any potential accrual of interest. Essentially, the theory assumes that no real rate of interest exists. See, for example, Beaulieu $v$ Elliott, 434 P2d 665, 671 (Alaska 1967) ("[J]ustice will best be served by permitting the trier of fact to compute loss of future earnings without reduction to present value."); Kaczkowski $v$ Bolubasz, $491 \mathrm{~Pa}$ 561, 421 A2d 1027, 1039 (1980) ("[T]he courts of this Commonwealth are instructed to abandon the practice of discounting lost future earnings.").

The few jurisdictions that have adopted this doctrine initially confined the rule to tort injuries. One court, however, used it to award undiscounted damages in a contract dispute. See Bloomfield Financial Corp v National Home Life Assurance Co., 734 F2d 1408,1413 (10th Cir 1984) (affirming the district court's ruling that the total offset rule would be applied in Pennsylvania to lost future commissions in a contract dispute). No other court, however, has extended this rule to contract cases, and the rule remains the minority position for tort cases.

${ }^{25}$ The following table illustrates the present value of annual profit streams over a ten-year period at varying discount rates:

Discount Rates

\begin{tabular}{|c|c|c|c|c|c|}
\hline Annusl Amounts & $8 \%$ & $9 \%$ & $10 \%$ & $11 \%$ & $12 \%$ \\
\hline$\$ 100,000$ & $\$ 671,010$ & $\$ 641,770$ & $\$ 614,460$ & $\$ 588,920$ & $\$ 565,020$ \\
\hline$\$ 500,000$ & $\$ 3,355,050$ & $\$ 3,208,850$ & $\$ 3,072,300$ & $\$ 2,944,600$ & $\$ 2,825,100$ \\
\hline$\$ 1,000,000$ & $\$ 6,710,100$ & $\$ 6,417,700$ & $\$ 6,144,600$ & $\$ 5,889,200$ & $\$ 5,650,020$ \\
\hline
\end{tabular}

${ }_{26}$ Using the table of discounted values in note 25 , one finds that the present value of a ten-year stream of $\$ 100,000$ payments at a 9-percent discount rate is $\$ 641,770$, and at a 10 -percent discount rate is $\$ 614,460$. The difference between these two amounts ( $\$ 641,770$ $-\$ 614,460$ ) equals $\$ 27,310$. (Note that the relationship between the discount rate and the amount of the damage award needed to fully compensate the plaintiff is an inverse one; the higher the discount rate, the lower the damage award, and vice-versa.) 
percent to 11 percent decreases the present value of the damage award by over $\$ 25,000{ }^{27}$ Indeed, the spread between an 8-percent discount rate and a 12-percent rate results in a damage award differential of over $\$ 100,000$. Moreover, as the table in note 25 vividly illustrates, the higher the potential profits, the greater the present-value differential associated with the discount rate. ${ }^{28}$ Thus, as the stakes increase, so does the importance of the discount rate.

\section{Discretion without guidance.}

Courts have treated the choice of discount rate as case specific, allowing complex calculations and vital assumptions to vary based on the nature of a given dispute. The selection of a discount rate is generally considered a finding of fact, not a matter of law, and thus the ultimate choice of the appropriate discount rate is the sole province of the fact finder, be it judge or jury. ${ }^{29}$ In jury trials, the judge usually instructs the jury in broad terms and lets them choose the discount rate based on expert testimony and other evidence. ${ }^{30}$ The Fifth Circuit's description of Texas's jury instruction for discounting damages in breach-of-contract cases reveals the broad discretion that fact finders enjoy:

27 Again, using the table in note 25, one finds that the present value of a ten-year stream of $\$ 100,000$ payments at a 10 -percent discount rate is $\$ 614,460$, and at an 11 -percent discount rate is $\$ 588,920$. The difference between these two amounts $(\$ 614,460$ $\$ 588,920$ ) equals $\$ 25,540$.

${ }^{28}$ On a contract worth $\$ 1$ million per year, a 1-percent increase or decrease in the initial 10-percent discount rate modifies the lost-profit award by over $\$ 250,000$. On a $\$ 10$ million-per-year contract, the differential would be over $\$ 2,500,000$.

${ }^{29}$ See generally Dobbs, 2 Law of Remedies $\S 8.5(3)$ at 472 (cited in note 4).

30 Under Federal Rule of Evidence 702, the trial court has broad discretion in admitting expert testimony. See Hamling $v$ United States, 418 US 87, 108 (1974) ("[T]he District Court has wide discretion in its determination to admit and exclude evidence, and this is particularly true in the case of expert testimony."); United States $v$ Beasley, 72 F3d 1518, 1528 (11th Cir 1996) (citing Hamling).

If the parties fail to offer evidence on the discount rate, they risk pure judicial formulation. See Taylor Publishing Co. $v$ Systems Marketing Inc., 686 SW2d 213, 217 (Tex Ct App 1984), where, in a case involving a breach of a computer lease, the trial judge took judicial notice of the discount rate in determining damages under the lease. The parties offered no evidence of the proper discount rate, but the Court of Appeals found that in Texas, "specific evidence of the present value discount rate is not required and the trial court may determine the present value of future damages." Id. See also Binghamton Masonic Temple Inc. $v$ City of Binghamton, 158 Misc 2d 916, 602 NYS2d 310, 313 (NY Sup Ct 1993) (refusing to hear expert testimony not offered at trial in case involving a breach of a loan agreement and taking judicial notice of the discount rate). 
The Texas cases are not ambiguous. Discounting of future damage awards is adequately handled by the trial judge if he simply instructs the jury that damages are equal to the "sum of money, if any, if paid now in cash" that would compensate the plaintiff. ... Texas courts refuse to amplify this simple instruction because they believe that further explanation would confuse the jury. ${ }^{31}$

This instruction tells fact finders only "to compensate," leaving them to decide how with few constraints and little guidance. ${ }^{32}$

Given this combination of broad discretion and little guidance, it is not surprising that juries regularly fail to understand the need to discount to present value, let alone the mechanics of finding the proper discount rate. Indeed, in the same case in which the Fifth Circuit affirmed Texas's simple jury instruction, it found that "although the instruction was correct, the jury evidently did not follow it." ${ }^{\text {33 }}$ Accordingly, the court remanded the case so that the trial judge could "determine an appropriate discount rate and compute the present value of the award for contract earnings."34 Other jurisdictions have experienced similar problems with jury discounting of damage awards. ${ }^{35} \mathrm{~A}$ few jurisdictions have tried to eliminate jury discretion in discounting, expressly leaving the choice of discount rates in tort cases up to the discretion of judges ${ }^{36}$ or even defining that rate by stat-

${ }^{31}$ Budge $v$ Post, 643 F2d 372, 375-76 (5th Cir 1981).

32 Other courts provide more guidance. For example, in Wingad v John Deere \& Co., 187 Wis 2d 441, 523 NW2d 274, 277 (Wis App 1994), the court reviewed the traditional Wisconsin jury instruction for evaluating future damages. The instruction provides a good common-sense description of present value, noting that "a sum received today can be invested and earn money at current interest rates." Id. The court found that "[i]n calculating present value, future payoffs by the rate of return offered by comparable investment alternatives are discounted. This rate of return is referred to as the discount rate. ... Evidence of a discount rate or range of discount rates, whether by stipulation or testimony, is needed in calculating present value." Id. Still, in Wisconsin the ultimate decision on the discount rate rests in the sole discretion of the jury. Id.

${ }^{33}$ Budge, 643 F2d at 376.

34 Id. The Fifth Circuit, however, did not define what the "appropriate" discount rate was.

${ }^{35}$ See, for example, Sierra Blanca Sales Co. $v$ Newco Industries, Inc., 88 NM 472, 542 P2d 52, 54 (NM App 1975) (reviewing a lower court's remittitur of a contract damage award after the jury had failed to follow the lower court's discount instruction).

${ }^{36}$ Section 5041(e) of New York's Civil Practice Law and Rules requires plaintiffs whose future damages in tort suits exceed $\$ 250,000$ to purchase "an annuity contract that will provide for the payment of the remaining amounts of future damages in periodic installments." NY Civ Prac L \& R \& 5041(e) (McKinney 1992). Judges must determine the present value of such a contract by "applying the discount rate in effect at the time of the award to the full amount of the remaining future damages." Id. The statute does not 
ute. ${ }^{37}$ No jurisdiction, however, has applied these innovations to contract disputes.

Judges must struggle with the same discretion and lack of guidance. Courts recognize that "[t]he discount rate is determined by financial markets at the time of termination, ${ }^{238}$ and that "[t]here is no question that in order to compute the present value of the damages a commercial interest rate [must] be determined." 39 But such broad proclamations are generally not instructive. When confronted with the task of selecting an appropriate discount rate in a contract dispute, courts can select from a panoply of possible interest rates, including the United States Treasury bill, note, or bond rate, as well as the AAA or high-yield corporate bond rate. Indeed, one court described the application of a New York statute that requires individual courts to select the "appropriate" discount rate as "every judge's nightmare."40 The fact finder-whether judge or jury-must therefore struggle without proper legal direction in performing the difficult but vital task of choosing the appropriate discount rate.

Even the Supreme Court has declined to adopt a standard to guide federal courts through the mechanics of discounting. In Jones \& Laughlin Steel Corp v Pfeifer, the Court refused to establish an exclusive method for calculating the present value of lost-earnings awards in federal trials. ${ }^{41}$ Specifically, the Court noted:

specify a discount rate; accordingly, "it is left to individual courts to determine an appropriate rate." In re New York Asbestos Litigation, 847 F Supp 1086, 1112 (S D NY 1994). See, for example, Reliant Airlines, Inc. $v$ County of Broome, 1995 US Dist LEXIS $14223, * 4-5$ (N D NY 1995) (unpublished opinion) (Court had to choose between three possible rates: plaintiff's expert's rate of 4.75 percent; plaintiff's alternative rate of 5.25 percent; and defendant's expert's rate of 6.11 percent.).

${ }_{37}$ See, for example, Mich Comp Laws Ann § 600.6306(2) (West 1987) (stating that the discount rate for present value calculations of future damages shall be " $5 \%$ per year for each year in which those damages accrue"); Ariz Rev Stat Ann $\S 12-589$ (A) (West 1992) (pegging the discount rate for tort awards to the most recent issue of the fifty-two-week United States Treasury bill sold before the date the damages are discounted).

${ }_{38}$ Bergkamp v Carrico, 108 Idaho 476, 700 P2d 98, 103 n 2 (Idaho App 1985).

39 CHR Equipment Financing, Inc. v C\&K Transport Inc., 448 NW2d 693, 695 (Iowa App 1989).

40 Rohring $v$ City of Niagara Falls, 153 Misc 2d 1001, 584 NYS2d 513, 513 (NY Sup Ct 1992) (construing NY Civ Prac L \& R \$ 5041(e); see note 36 for a discussion of this statute). Because the New York statute applies to lost future earnings for individuals, see note 36, courts may have less trouble determining the appropriate discount rate because they can employ the general "best and safest investments" standard. See text accompanying note 8. But if the New York process is a "nightmare" in the individual context, it can only be more difficult for judges to figure out a discount rate for commercial parties, to which multiple and more exacting standards can be applied.

4162 US 523, 546-47 (1983). 
[B]y its very nature the calculation of an award for lost earnings must be a rough approximation. Because the lost stream can never be predicted with complete confidence, any lump sum represents only a "rough and ready" effort to put the plaintiff in the position he would have been in had he not been injured. ${ }^{42}$

Moreover, the Court counseled that "[w]e do not suggest that the trial judge should embark on a search for 'delusive exactness.' It is perfectly obvious that the most detailed inquiry can at best produce an approximate result. ${ }^{\prime 43}$ Ultimately, the Court concluded that "whatever rate the District Court may choose to discount the estimated stream of future earnings, it must make a deliberate choice." Accordingly, as long as a court is "deliberate," its selection of discount rates will likely satisfy the Court's standard.

\section{Random results and uncertain rationales.}

Because the law generally invests fact finders with such broad discretion and so little guidance, discount-rate selection-especially in contract disputes-lacks rhyme and reason. Commentators have noted that "[a] review of judgments awarded by the courts reveals a hodge-podge of approaches and theories on which awards have been rendered." ${ }^{35}$ One court described "the case law with regard to an appropriate discount rate ... [as] a 'many-colored splendor' of conflicting and sometimes indecipherable formulas." ${ }^{36}$ Discretion has left the law in disarray.

Decisions regarding lost future profits reveal a wide variety of selected rates, often without any strong economic rationale. For example, courts have found a rate of 25 percent to be "substantial and conservative, ${ }^{\$ 77}$ a rate of 7 percent to be "fair and reasonable," ${ }^{\prime 48}$ and a rate of 6 percent to be "appropriate," all with little or no explanation. Moreover, the Second Circuit upheld without comment a jury's decision to discount the lost future

42 Id at 546.

43 Id at 552 .

4 Id at 552-53.

45 R.F. Lanzillotti and A.K. Esquibel, Measuring Damages in Commercial Litigation: Present Value of Lost Opportunities, 5 J Acct Aud \& Fin 125, 125 (1990).

${ }^{4}$ In re Computer Optics, Inc., 126 Bankr 664, 671 (Bankr D NH 1991).

17 See Mirafi, Inc. $v$ Murphy, 1989 US Dist LEXIS 16399, *36 (W D NC 1989) (unpublished opinion).

(8) See Bridgkort Racquet Club, Inc. v University Bank, 85 Wis 2d 706, 271 NW2d 165, 170 (Wis App 1978).

19 See Groendyke Transport, Inc. v Merchant, 380 P2d 682, 686 (Okla 1962). 
profits of a broken liquor-distribution agreement at a 17-percent rate even though the expert testifying at trial had discounted the award by a 9-percent rate. ${ }^{50}$ Indeed, the court focused on evidentiary points and ignored the $\$ 140,000$ differential between the expert and jury outcomes. ${ }^{51}$

Fact finders, however, usually just accept one expert's opinion or even split the difference between competing experts or possible methodologies. "[C]ourts [recognize] that the term 'discount rate' has no fixed meaning and have accepted discount rates testified to by a party's economist at trial." ${ }^{n 3}$ Indeed, one experienced expert remarked that "[ $t]$ he opinion of an expert on damages is usually given great deference by the trial court. ${ }^{254}$ Most decisions merely state their agreement with an expert's conclusion without any explanation and then go on to other topics. ${ }^{55}$ By generally deferring to financial experts, judges and juries ease their own decisional burdens and encourage parties to use experts during the trial.

The reasoning of many courts has therefore been far from "deliberate." Battered by financial formulae and confused by conflicting expert testimony, fact finders operate a perverse legal lottery that commercial parties are obliged to play. Uncertainty

so See Lee $v$ Joseph E. Seagram \& Sons, Inc., 552 F2d 447, 455 (2d Cir 1977).

31 Id.

${ }_{52}$ Courts will occasionally surprise experts and parties. In American List Corp $v$ U.S. News and World Report, Inc., 75 NY2d 38, 550 NYS2d 590 (1989), New York's highest court rejected a lower court's finding of an 18-percent discount rate in a breach-of-contract suit. The lower court had discounted lost future profits at 18 percent based on the testimony of the defendant's expert witness. Id at 594. The Court of Appeals, however, rejected this discount rate because it included a premium for the risk that the plaintiff would not perform the contract. The Court held that this risk may not properly be considered in damages for anticipatory breach and remanded the case for the determination of a proper discount rate. Id.

${ }^{63}$ Binghamton Masonic Temple, Inc. $v$ City of Binghamton, 158 Misc 2d 916, 602 NYS2d 310, 313 (NY Sup Ct 1993).

s4 Blair, 8 Franchise $L \mathrm{~J}$ at 3 (cited in note 4).

${ }_{55}$ See, for example, LLECO Holdings, Inc. $v$ Otto Candies, Inc., 867 F Supp 444, 451 (E D La 1994) (discounting lost future profits of an oil and gas lease at a rate of 25 percent after accepting an expert's testimony that the 25-percent figure was "more appropriate in figuring a fair return on investment for plaintiffs"); Westman Commission Co. $v$ Hobart Corp, 541 F Supp 307, 317 (D Colo 1982) (accepting expert's use of a 16.8-percent rate to discount lost sales); Fen Hin Chon Enterprises, Ltd. v Porelon, Inc., 667 F Supp $1174,1186-87$ (M D Tenn 1987) (accepting expert's use of 6.5-percent rate to discount future profits from breach of a licensing agreement). See also Claims Mediator in Columbia Bankruptcy Case Recommends Methodology for Recalculating Producer Contract Rejection Claims on Uniform, Comparable Basis, Foster Nat Gas Rep (No 2001) 1, 2-3 (Oct 20,1994 ) (reporting that a mediator chose a discount rate falling between rates offered by various parties). 
and unnecessary expense thus prevail in a system without a clear default rule.

\section{EXPERT ANSWERS FOR COMMERCIAL PARTIES}

One could argue that courts should continue to defer to experts or that they should simply pick the most popular financial methodology and use it as the default rule, thus handing the discount decision over to the experts. Experts, however, currently offer courts a vast assortment of "appropriate" discount rates in commercial-contract disputes, and each option ultimately fails as a proper default rule. Indeed, each of the usual theories fails to justify itself on simple cost-benefit principles.

The following analysis reviews and criticizes five approaches that expert commentators have employed or examined when finding the specific discount rate in lost-profiits disputes. ${ }^{56}$ finance that experts commonly use in advocating specific discount rates in lost-profits disputes. A basic understanding of these methodologies is necessary to clarify and to critique the discounting debate. Three issues cut across each of the approaches reviewed in this section: unsettled theories, the potential for bias, and high costs.

First, finance offers no one "best" way to find the appropriate discount rate in commercial-contract disputes. Comentators have only recently tackled the problem of damage valuation in commercial litigation. ${ }^{57}$ Accordingly, multiple approaches have sprung up, taking the varied perspectives of the plaintiff, the

56 This section surveys the practicioner literature on the discounting of profits in commercial settings. The section attempts to explain some basic terminology, but is not intended as a full discussion of finance theory, which begins discount rate selection in project valuation with the capital asset pricing model ("CAPM") and builds up to the weighted average cost of capital ("WACC"). Rather, this section focuses on general approaches and terms that courts may have dealt with before, organized from the most familiar to the least familiar.

${ }^{57}$ See generally Allen Michel and Israel Shaked, Valuation of Damage Claims: An Application of Corporate Finance, $19 \mathrm{~J}$ Bus Fin \& Acc 455, 455 (1992) (finding that "the issue of damage valuation has received virtually no consideration"); James E. Meyer, Patrick Fitzgerald, and Mostafa Moini, Loss of Business Profits, Risk, and the Appropriate Discount Rate, $4 \mathrm{~J}$ Legal Econ 27, 27 (1994) (noting that "little has been written on what constitutes the proper discount rate to be applied to lost future business profits").

In contrast, commentators have written extensively on discounting lost future earnings of individuals in the tort context. See generally Anderson and Roberts, $39 \mathrm{U}$ Miami L Rev 723 (cited in note 8); Slesnick, 14 U Dayton L Rev 81 (cited in note 8); Thomas Havrilesky, New Evidence on Expected Long Term Interest Rates, $1 \mathrm{~J}$ Forensic Econ 19 (1988). For a discussion of why this tort commentary is not directly applicable to contract adjudication, see note 8 . 
defendant, or even the market. ${ }^{58}$ Each method, however, brings its own complications and its own unique results. Because financial experts themselves disagree over proper discounting techniques, courts cannot point to a dominant method that parties could comfortably accept.

Second, experts can manipulate assumptions and numbers to favor the party that employs them. ${ }^{59}$ Experts agree that the application of theory to practice requires more pioneering work and allows for great creativity. ${ }^{60}$ Financial models are easy to build, but their implementation involves making assumptions and other contentious decisions that lead to varied results. Accordingly, not only can experts choose among competing theories, but they can manipulate a given theory to produce more favorable results. This potential for bias presents a salient problem whenever a financial expert testifies.

Finally, experts and expert testimony are costly to the parties and to the court system, and the benefits of allowing experts to fight it out at trial probably do not outweigh these costs. Given the incentives to present expert evidence, the lack of consensus among financial experts regarding discounting, and the inability of fact finders to understand the underlying economic analysis, the current regime encourages parties to overinvest in litigation for an uncorrelated return. For all these reasons, deferring to the experts is not a wise decision when constructing the proper discount default rule.

s8 Commentators do agree that experts disagree over the appropriate discount rate. See, for example, Terence F. Cuff, Present Value and Internal Rate of Return, LA Lawyer 25, 25 (June 1991) ("How do you choose the correct discount rate? There is a lively debate among economists and other experts about what is an appropriate discount rate in particular circumstances.").

${ }_{59}$ See, for example, Contract Lodging Corp $v$ Union Pacific Railroad, 1991 US Dist LEXIS 18663, *4 (D Kan 1991) (unpublished opinion) (ignoring attempted expert manipulation of the discount rate after parties had stipulated to a rate of 7.5 percent).

6o Michel and Shaked close their article with the following admonition and appeal:

Even though the academic world is adept at developing complex models, when it comes to the courtroom, applying these models in an understandable and convincing way is a challenge. We look forward to having more academics share their experiences as expert witnesses, thereby closing the gap between the world of finance and the world of law. 


\section{A. Weighted Average Cost of Capital}

Some commentators have argued that courts should use a formulaic average of the plaintiff's cost of capital or the costs of a firm's various components of financing to determine the appropriate discount rate. ${ }^{61}$ Financial experts first calculate the individual components of a firm's capital structure, primarily the firm's cost of debt (interest on borrowing) and cost of various stock issues (rate that investors require the firm to earn on its equity). ${ }^{62}$ These components are then weighted according to some standard (usually the relative proportions that the components represent in the existing capital structure) ${ }^{63}$ and then averaged according to the proposed weights. ${ }^{64}$

61 See id at 455 (presenting a case study applying the cost-of-capital method to the valuation of damages from a broken contract). Other commentators advocate the use of the cost-of-capital approach but argue that the ultimate discount rate should be adjusted for the risk of the project. See Lanzillotti and Esquibel, $5 \mathrm{~J}$ Acct Aud \& Fin at 132 (cited in note 45) ("[T]he plaintiff's damage award for profits . . . is the present value of the future profits discounted to the time of the award by the cost of capital adjusted to the risk of the project."). Lanzillotti and Esquibel, who claim that "the uncertain future lost profits are the easiest to deal with," id at 130, fail to explain how one should measure a firm's cost of capital or how one should adjust the discount rate to the risk of the project.

${ }_{62}$ See James C. Van Horne, Financial Management and Policy 235 (Prentice-Hall 9th ed 1992).

${ }_{63}$ Id at 241-43. Van Horne notes, however, that the relative weights should correspond to the proportions of financing that the firm intends to employ, thus allowing a firm to maintain a constant capital structure over time for purposes of the relative-weight calculations. Id. Specifically, Van Horne notes that in practice, "[r]aising capital is Tumpy,' and strict proportions cannot be maintained." Id at 243. Therefore, "[o]ver time, most firms are able to finance in roughly a proportional manner. ... In other words, weighted average cost of capital calculations should ignore temporary deviations from a target capital structure, even though these deviations detract from the theoretical correctness of the weighted average cost method." Id. This subtle difference between the intended financing of a firm's capital structure and its actual financing illustrates just one of the many elements in the cost-of-capital calculation that is subject to manipulation. See note 75 and accompanying text.

64 Accordingly, the weighted average cost of capital ("WACC") is expressed as follows:

WACC $=($ Proportion of Debt $)($ Debt Cost $)+($ Proportion of Equity $)($ Equity Cost $)$

Id at 217. Van Horn also provides an example to illustrate the mechanics of this formula:

\begin{tabular}{|l|c|c|c|}
\hline $\begin{array}{l}\text { Company X: } \\
\text { Balance Sheet }\end{array}$ & (1) Amount & (2) Proportion & (3) Cost \\
\hline Debt & $\$ 30$ million & $30 \%$ & $7.20 \%$ \\
\hline Preferred Stock & $\$ 10$ million & $10 \%$ & $11.37 \%$ \\
\hline Common Stock Equity & $\$ 60$ million & $60 \%$ & $15.00 \%$ \\
\hline
\end{tabular}


The weighted average cost of capital represents a firm's baseline for investment decisions and is thus conceptually appealing as the basis for discounting lost profits. Under contemporary finance theory, firms seek to maximize shareholder wealth. ${ }^{65}$ If a firm finances in the proportions specified in the formula and accepts only those projects yielding more than the weighted average required return, then the marketplace will recognize that the company's returns should outpace its costs. Accordingly, investors will want to share in this boon, the market price of the stock should rise, and shareholders will benefit from an appreciation of their holdings. ${ }^{66}$

A court could simply appropriate this weighted average rate to discount lost future profits. ${ }^{67}$ The cost of capital represents a rate of return that companies will try to earn to satisfy their owners and stay in business. A judge or jury can thus rest assured that the company will invest its profits at this minimum rate. Accordingly, discounting future profits by the cost of capital will effectively compensate the injured party.

Although theoretically appealing, the cost-of-capital approach contains a number of practical pitfalls. First, experts reign over cost-of-capital analysis. Complex calculations, critical assumptions, and practical finesse constitute the financial expert's work. $^{68}$ While judges and juries may understand the theory,

\begin{tabular}{|l|c|c|c|}
\hline TOTALS & $\$ 100$ million & $100 \%$ & - \\
\hline WACC: $\Sigma[(2) \times(3)]$ & - & - & $12.30 \%$ \\
\hline
\end{tabular}

See id at 241-42.

${ }^{65}$ For a discussion of this fundamental postulate of finance, see id at 6-8.

66 Id at 244.

67 See, for example, Fishman $v$ Estate of Wirtz, 807 F2d 520, 580-81 (7th Cir 1986) (Easterbrook dissenting) (arguing for the use of the plaintiff's cost of capital as the appropriate discount rate in a tortious interference with prospective advantage dispute); Northern California Power Agency v FERC, 37 F3d 1517, 1522-23 (DC Cir 1994) (finding that a utility's cost of capital was the appropriate basis for a 15-percent discount rate used by the Federal Energy Regulatory Commission in a relicensing dispute).

See Michel and Shaked, $19 \mathrm{~J}$ Bus Fin \& Act at 455-60 (cited in note 57) for a case study measuring the cost of capital for a liquor distributor in a breach-of-contract dispute. The article reveals the many formulae, calculations, and assumptions that the finance team employed to figure out the appropriate discount rate based on the business's cost of capital. Except for basic statistical regression analyses, the mathematics were generally limited to simple algebra. The choice of appropriate formulae and proper data, however, required significant experience and strong financial intuition. Indeed, as the authors note in their analysis, as compared to calculating lost cash flows, the "cost of capital was less straightforward." Id at $\mathbf{4 5 7 .}$ 
they generally lack the training and intuition necessary to understand the underlying methodology. ${ }^{69}$

Second, the cost-of-capital theory requires a number of assumptions with regard to risk that are "extremely binding" and reduce its effectiveness as a predictive model. ${ }^{70}$ Ultimately, the theory assumes that all the projects of a firm enjoy the same level of risk and that the firm will only accept a new project that bears an equivalent level of risk. ${ }^{11}$ If each investment bore the same risk, each would earn the same rate of return, and the firm's overall cost of capital would be the appropriate baseline for investment decisions. ${ }^{72}$ In the everyday life of firms that must deal with investment proposals of varying risk, however, "the use of an overall required rate of return is inappropriate."73 Instead, a real firm will calculate a required rate of return for specific investment proposals, and this rate will not necessarily correlate with the firm's overall cost of capital. Accordingly, judges and juries cannot be assured that a firm's cost of capital is truly its baseline for investment decisions. ${ }^{74}$

Third, the methodology allows for manipulation. Each variable in this long and complex process involves important decisions on what data to use and what approximations to make. ${ }^{75}$

69 Michel and Shaked reveal that in their analysis, "the legal team suggested that the simpler the model, the more positive effect it will have on the judicial decision." Id at 458 .

${ }_{70}$ Van Horne, Financial Management at 246 (cited in note 62).

71 Id.

72 For a discussion of how risk and return are directly related, see text accompanying notes 106-12.

73 Van Horne, Financial Management at 246 (cited in note 62).

74 One might argue that if a broken contract covered a specific project for which the injured company had calculated an expected return, the fact finder could then defer to the failed project's specific rate of return as the appropriate discount rate. But this specific rate of return may still undercompensate the injured party if, at the time of the damage award, the injured party is no longer able to earn the same return. Moreover, ambiguity still plagues the cost-of-capital analysis for the specific project, allowing for manipulation and a repeat of the legal lottery. Accordingly, this proposal would not serve as a proper default rule even if such information were in fact available to the fact finder.

${ }^{75}$ Michel and Shaked provide an honest description of their reasoning process and reveal how difficult it is to fit reality into financial categories. $19 \mathrm{~J}$ Bus Fin \& Acct at 455-60 (cited in note 57). Indeed, the authors reveal that:

[D]eriving a reliable estimate of a damage claim necessitates the use of numerous aspects of financial theory. The expert testimony presented in this paper includes the application of methodologies such as analyzing the yield curve, using the capital asset pricing model, determining the cost of capital, and applying the appropriate cost of capital framework. 
Experts have no fixed standard by which to judge their work, and thus they may be creative in reaching their results. ${ }^{76}$ According$\mathrm{ly}$, "reasoned applications of financial and economic theory may produce different, yet defensible, results.."77

Ultimately, the cost-of-capital model's conceptual appeal weakens with its attendant costs. Experts are expensive, judges and juries will rarely understand their methods, and parties must invest in an uncorrelated chance that the fact finder will believe one expert over another, or perhaps split the difference. ${ }^{78}$ In the meantime, commercial parties must deal with this uncertainty and the distorted settlement incentives it produces. ${ }^{79}$ If this were a voluntary investment decision, commercial parties would undoubtedly avoid it altogether.

\section{B. Internal Rate of Return}

Another conceptually appealing measure is a company's internal rate of return ("IRR") for the project covered by the broken contract. The IRR "is the average percentage rate per period that invested dollars are earning."180 For a specific project, its computation yields a "discount rate such that the sum of the present values of expenditures will equal the sum of the present values of returns from the investment. ${ }^{n 81}$ The resulting rate of return is then compared to a "threshold" or "hurdle" rate to judge the investment's feasibility. ${ }^{82}$ The IRR thus seems appropriate

${ }^{78}$ See text accompanying notes 57-60.

77 Lanzillotti and Esquibel, $5 \mathrm{~J}$ Acct Aud \& Fin at 141 (cited in note 45).

${ }^{78}$ Certainly, this probabilistic return is an aspect of expert testimony in any area of the law. This Section is intended to demonstrate, however, that in the case of choosing a discount rate in a commercial-contract dispute, expert testimony may not be necessary or even particularly helpful. Rather, courts could avoid inflicting unnecessary uncertainty and expense on commercial parties by adopting a default rule that eliminated the need for experts.

${ }^{79}$ For a discussion of settlement incentives, see text accompanying notes 146-49.

so Kenneth J. Boudreaux and Hugh W. Long, The Basic Theory of Corporate Finance 31 (Prentice-Hall 1977).

B1 Cuff, Present Value, LA Lawyer at 26 (cited in note 58). In other words, the IRR is "that discount rate $X$ such that the sum of all the positive cash flows discounted at $X$ and negative cash flows discounted at X will equal zero." Id. See also Van Horne, Financial Management at 141 (cited in note 62) (defining IRR as the "discount rate that equates the present value of the expected cash outflows with the present value of the expected inflows").

${ }_{82}$ See James E. Hodder and Henry E. Riggs, Pitfalls in evaluating risky projects, 63 Harv Bus Rev 128, 130 (Jan-Feb 1985) (applying and criticizing IRR techniques); Van Horne, Financial Management at 142 (cited in note 62) (noting that "[t]he acceptance criterion generally employed with the internal-rate-of-return method is to compare the internal rate of return with a required rate of return, known also as the cutoff, or hurdle, 
as the rate with which to discount lost profits because it represents the break-even return that a company expects to receive on the investment that it made in the breached contract.

Financial experts, however, avoid using this measure to discount future profits, and courts should not be fooled into accepting it as the appropriate discount rate. First, the IRR is a method for evaluating projects, not calculating discount rates. Second, even as a method of evaluation, the IRR suffers from a number of pitfalls. Rates of return on investments change over time, and thus "[o]nly rarely will the internal rate of return calculated represent the relevant rate for reinvestment of intermediate cash flows." ${ }^{83}$ Second, calculation of the IRR is highly complex: normal algebra is of no assistance, and even "calculators and computers that solve for internal rates of return do so by trial and error." ${ }^{284}$ Finally, "the choice of the threshold rate of return is arbitrary in nature and is specific to each particular investment." 85 Accordingly, the IRR methodology presents compa-

rate").

Van Horne, Financial Management at 147 (cited in note 62). See also Cuff, Present Value, LA Lawyer at 27 (cited in note 58).

${ }^{84}$ Cuff, Present Value, LA Lawyer at 26 (cited in note 58). The formula can be represented mathematically as:

$$
A_{0}=\frac{A_{1}}{(1+r)^{1}}+\frac{A_{2}}{(1+r)^{2}} \cdots \frac{A_{n}}{(1+r)^{n}}
$$

where $A_{0}$ is the initial expenditure or cash outlay, $n$ is the period when the investment will generate cash flows, $A_{1}$ through $A_{n}$ represents expected cash inflows, and $r$ is the discount rate that equates these outflows and inflows. See Van Horne, Financial Management at 22-24 (cited in note 62).

Ordinarily, one cannot perfectly equate the present value of disparate cash flows. One discount rate might make one cash flow slightly greater than the other; another rate might make the same cash flow slightly less than the other. Parties must thus choose whichever one they think approximates equivalency. Cuff explains:

There can be many solutions to the discount rate, some of which may seem like nonsense. It is not unusual for there to be both positive and negative interest rates that will solve the internal-rate-of-return equation. ... It will be important to specify the specific range of acceptable values. ... Otherwise, you may end up in a legal dispute over a high order mathematical equation.

Cuff, Present Value, LA Lawyer at 26-27 (cited in note 58).

${ }_{85}$ Gilbert, $4 \mathrm{~J}$ Legal Econ at 42 (cited in note 16). See also Cuff, Present Value, LA Lawyer at 27 (cited in note 58):

An investment with a 15 percent internal rate of return is not necessarily better than an investment with a 10 percent rate of return; in fact, the 10 percent may be better. This can depend on the investor's return on invested funds, the risk of the invest- 
nies with multiple, difficult-to-calculate, and somewhat arbitrary solutions. Financial experts generally avoid this method to measure future damages and so should the legal system.

\section{Coerced-Loan Theory}

Some commentators have suggested that when the defendant owes the plaintiff money for a breach of contract, the plaintiff in effect becomes a creditor of the defendant. Accordingly, the proper discount rate should be based on the defendant's general cost of debt, or on a particular debt instrument that replicates the plaintiff's position as a "creditor. ${ }^{386}$ Thus, a court must consider the defendant's cost of capital or find the interest rate that the defendant would pay voluntary creditors who took the same position in the capital structure as the plaintiff involuntarily took. ${ }^{87}$

Although interesting as an analogy, this approach fails as a proper default rule for contract disputes. First, a discount rate based on the defendant's cost of debt does not measure what the plaintiff might earn on its own investments. The plaintiff had no choice in becoming a forced creditor of the defendant, and perhaps could have obtained a more attractive investment elsewhere. Accordingly, its coerced "loan" to the defendant does not

ment, and the relationship between the investment and the investor's other investments.

so See James M. Patell, Roman L. Weil, and Mark A. Wolfson, Accumulating Damages in Litigation: The Roles of Uncertainty and Interest Rates, $11 \mathrm{~J}$ Legal Stud 341, 342 (1982). Although Patell, Weil, and Wolfson apply the coerced-loan model to presettlement interest (the interest accrued between breach and settlement date), this model is also applicable to discounting future streams of income. Indeed, some courts now use it to value creditor claims in bankruptcy reorganization proceedings. See Michael E.S. Frankel, Comment, The Emerging Fixed Cramdown Rate Regime: A Market-Driven Argument for Effective Fixed Rates in Bankruptcy Cramdown, 2 U Chi L Sch Roundtable 643, 648-49 (1995) (examining various circuit courts' use of the coerced-loan theory to value creditor claims in reorganization "cramdown" proceedings).

${ }^{87}$ The plaintiff's position as a voluntary creditor, and the interest rate that it accordingly enjoys as a creditor, will ultimately depend upon its hypothetical priority in bankruptcy. Thus, a court will have to work backward from bankruptcy, viewing the plaintiff as a voluntary creditor taking part in the defendant's capital structure, to determine the interest rate that the plaintiff should earn on its lost profits. The court could then use this number as the discount rate. See Michael S. Knoll, A Primer on Prejudgment Interest 18-22 (unpublished manuscript on file with $U$ Chi $L$ Rev). In reorganization proceedings, this analysis is relatively straightforward because the plaintiff is already a secured creditor, and courts merely have to determine the going rate for similar loans in the particular region. See, for example, In re Hardzog, 901 F2d 858, 860 (10th Cir 1990) (finding that "the current market rate used for similar loans in the region" is the appropriate discount rate to find the present value of secured claims under the coerced-loan theory). 
represent a decision to funnel excess capital into projects that earn the best possible returns to maximize shareholder wealth. The plaintiff has contracted for services or goods, not to become an investor in the defendant's enterprise.

Second, the model is difficult to implement in practice. Measuring the discount rate by the defendant's cost of capital is subject to the same failings as measuring by the plaintiff's cost of capital, analyzed above. ${ }^{88}$ Alternatively, trying to categorize the plaintiff as a specific creditor is a complex and confusing endeavor. ${ }^{89}$ Should the court liken the plaintiff to a senior creditor or an unsubordinated debenture holder? Is the plaintiff's claim similar to a callable or convertible bond? Should the interest rate be fixed or floating? No court is prepared to answer these questions on its own and experts can haggle over each and every element. Theoretically unsound and practically unmanageable, the coerced-loan model is thus inappropriate as a contract default rule.

\section{Capitalization Factor}

Some experts completely bypass the present-value mechanics and the discount-rate debate by divining a simple market capitalization multiple to discount the stream of future losses. "The capitalization of earnings from a business enterprise represents an attempt to determine the value of a going business." ${ }^{\prime 1}$ Accordingly, "[a] capitalization factor is the ratio of the value of a stream of continuing income to the current amount of the stream; for example, if a firm is worth $\$ 1$ million and its current earnings are $\$ 100,000$, its capitalization factor is ten. ${ }^{.92}$ Like the price-to-

83 See Section II.A. Note also that the defendant's breach may reflect a shaky financial condition that the financial markets have already internalized. Accordingly, the defendant's cost of capital may be high because its ability to operate as a going concern is uncertain. The appropriate discount rate under the coerced-loan model will therefore be high, reducing the plaintiff's damage award to a low present value. Thus, the reasoning behind the damage award would fail to reflect how the plaintiff may actually invest the funds.

89 See Knoll, Primer on Prejudgment Interest at 19-36 (cited in note 87), for a discussion of how a court should choose the appropriate prejudgment interest rate under this model.

${ }^{20}$ See generally Allen S. Joslyn, Measures of Damages for the Destruction of a Business, 48 Brooklyn L Rev 431 (1982); Robert E. Hall and Victoria A. Lazear, Reference Guide on Estimation of Economic Losses in Damages Awards, in Reference Manual on Scientific Evidence 471, 497 (Fed Jud Center 1994).

91 Joslyn, 48 Brooklyn L Rev at 456 n 93 (cited in note 90), citing Arthur Stone Dewing, 1 The Financial Policy of Corporations 287 (Ronald 5th ed 1953).

${ }^{82}$ Hall and Lazear, Reference Guide at 498 (cited in note 90). 
earnings ratio used in evaluating stocks, ${ }^{93}$ the capitalization factor basically measures the amount of money that investors are willing to pay for each dollar of current income of a company.

Experts generally calculate this measure by using the injured company's accounting records and the market values of comparable businesses. ${ }^{94}$ The figure is then adjusted by factors such as "the general economic outlook, the outlook for the specific industry, the past history of the business in general, and the prospect that the business will continue. ${ }^{995}$ Once an expert has computed this "cap factor," the value of the loss is easy to determine: simply multiply the capitalization factor by the current profit from the broken contract. ${ }^{96}$ Accordingly, experts can avoid the normal present value methodology and value future profits with market information and simple multiplication.

Courts have found this method intuitively appealing in analogous settings. Because the cap factor approximates the amount that investors are willing to pay for a dollar of current income, courts can simply defer to how the market values a company's future earnings and avoid a subjective determination of what value the company itself expects to gain from its earnings. Many courts have followed this rationale in awarding lost earnings for antitrust violations, applying the cap-factor analysis to plaintiffs

93 The price-to-earnings ratio is the ratio of the current market price of a stock to its earnings per share. See Diamond, Financial Accounting at 710 (cited in note 20). Experts often appropriate this well known financial measure to derive the appropriate capitalization factor. See Joslyn, 48 Brooklyn L Rev at $457 \mathrm{n} 98$ (cited in note 90).

24 Joslyn, 48 Brooklyn L Rev at 457 (cited in note 90 ).

85 Id.

Hall and Lazear offer the following example:

\begin{tabular}{|l|c|}
\hline $\begin{array}{l}\text { (1) Ratio of market value to current annual earnings in comparable } \\
\text { publicly traded firms: }\end{array}$ & 13 \\
\hline (2) Plaintiff's lost earnings over past year: & $\$ 200$ \\
\hline (3) Value of future lost earnings [(1) $\mathrm{x}(2)]:$ & $\$ 2600$ \\
\hline
\end{tabular}

Reference Manual at 498 (cited in note 90 ).

One can construe the example above as representing a five-year contract where the injured party expected $\$ 200$ of profit per year. An expert would then use all financial information-including the term of the contract-to calculate the cap factor. A court could then simply multiply the factor by the first year's expected profits to find the profits due to the injured party upon breach. 
as diverse as automobile-part-distributors ${ }^{97}$ and Sony product dealers. ${ }^{98}$

Despite its practical and intuitive simplicity, this methodology is inapt for breach-of-contract awards. A capitalization factor appraises the market value of a company's future stream of income as if the company were being sold. This method misses the mark of measurement: courts are concerned with how the plaintiff can invest an award today to reach a certain sum tomorrow, not how the market values this sum. The latter measures what the market expects to earn on an investment in the plaintiff; the former measures what the plaintiff expects to earn on the market. Contract law, however, generally focuses only on how the plaintiff can voluntarily invest the damage award. ${ }^{99}$ Thus, like the coerced-loan theory, the capitalization method approaches the discounting of damages from the wrong perspective..$^{100}$

Furthermore, the capitalization method involves all the costs of the cost-of-capital method but adds no new benefits. ${ }^{101}$ Parties must use experts to calculate the appropriate multipliers, thus increasing litigation costs. ${ }^{102}$ Moreover, "parties may dispute almost every element of the capitalization calculation," including "whether there is reliable evidence that the capitalization factor accurately measures value for the specific asset or business. ${ }^{103}$ Accordingly, the battle of the experts will produce disparate results at great cost and the parties will once again face uncertainty. Courts should therefore refrain from adopting this approach as the default rule. ${ }^{104}$

${ }^{97}$ See Tires Sales Corp v Cities Service Oil Co., 637 F2d 467, 476 (7th Cir 1980) (overruling district court's acceptance for directed verdict of a 9.25 cap factor to discount the lost earnings of a wholesale distributor of automobile accessories, but only because the issue should have been presented to the jury).

${ }^{98}$ See Eiberger $v$ Sony Corp of America, 459 F Supp 1276, 1289 (S D NY 1978) (applying a cap factor of fifty to a Sony products dealer). For other examples of courts using the cap-factor method in antitrust cases, see Vandervelde $v$ Put \& Call Brokers \& Dealers Association, 344 F Supp 118, 152 (S D NY 1972) (applying a multiple of three to discount the future earnings of a broker business); Taxi Weekly, Inc. $v$ Metropolitan Taxicab Board of Trade, Inc., 539 F2d 907, 914-15 (2d Cir 1976) (upholding a jury verdict that accepted an expert's cap factor of ten).

99 See notes 16-20 and accompanying text.

100 For a discussion of how the coerced-loan theory takes the wrong perspective, see Section II.C.

101 For a discussion of the faults of the cost-of-capital method, see Section II.A.

102 Joslyn notes that under the cap-factor analysis, "the plaintiff will need expert testimony regarding the proper rate of capitalization." 48 Brooklyn L Rev at 456 (cited in note 90 ).

${ }^{103}$ Hall and Lazear, Reference Manual at 498 (cited in note 90).

${ }_{104}$ See Meyer, Fitzgerald, and Moini, $4 \mathrm{~J}$ Legal Econ at 31 (cited in note 57) (conclud- 


\section{E. Capital Asset Pricing Model}

Finally, one group of financial experts has recently proposed an adjusted capital-asset-pricing model ("CAPM") to calculate the appropriate discount rate ${ }^{105}$ Pioneered by William Sharpe ${ }^{106}$ the CAPM suggests that the return of an asset $\left(R_{j}\right)$ is influenced by the prevailing risk-free rate $\left(R_{f}\right)$ (usually the United States Treasury bill rate), the market return $\left(R_{m}\right)$ (perhaps the return on the Standard \& Poor's 500), and the covariance ${ }^{107}$ between $R_{j}$ and $R_{\mathrm{m}}\left(\beta_{\mathrm{j}}\right)$ as follows: ${ }^{108}$

where

$$
R_{\mathrm{j}}=R_{\mathrm{f}}+\beta_{\mathrm{j}}\left(R_{\mathrm{m}}-R_{\mathrm{f}}\right),
$$

$$
\beta_{j}=\frac{\operatorname{cov}\left(R_{j}, R_{m}\right)}{\operatorname{var}\left(R_{m}\right)}
$$

The CAPM measures what is intuitively obvious to most investors: the greater the unavoidable risk of a security (the risk that cannot be diversified away), the greater the return that an investor will expect from this security. ${ }^{109}$ The correlation, or sensitivity, between a security's excess returns and the market's excess returns as a whole is measured by beta $(\beta) .{ }^{110}$ If $\beta=1$, then the stock's excess returns vary proportionally with the market's returns; if $\beta>1$, then the stock's returns vary more than proportionally; and if $\beta<1$, then the stock's returns vary less than proportionally. Thus, the greater the beta, the greater the risk, and the greater the expected return. ${ }^{111}$

ing that the cap-factor method of determining damages "while being simple is probably inaccurate").

105 See id at 27. Lanzillotti and Esquibel appear to refer to this type of method when they suggest that the proper approach is the "cost of capital adjusted to the risk of the project." $5 \mathrm{~J}$ Acct Aud \& Fin at 132 (cited in note 45).

${ }_{108}$ See generally William F. Sharpe, Capital Asset Prices: A Theory of Market Equilibrium under Conditions of Risk, $19 \mathrm{~J}$ Fin 425 (1964).

107 "Covariance" is a statistical measure that essentially means "to vary with." In the example, $\beta_{j}$ measures how a certain security's return $R_{j}$, may "vary with" the market as a whole.

${ }^{108}$ See Jeff Madura, Financial Markets and Institutions 205 (West 2d ed 1992).

100 See Van Horne, Financial Management at 64 (cited in note 62).

110 Id at 66.

111 "A higher beta reflects a higher covariance between an asset's returns and market returns, which contributes more risk to the portfolio of assets held by the investor." Madura, Financial Markets at 205 (cited in note 108). Accordingly, an investor will want 
Viewing the firm's assets as a portfolio of investments, experts can apply the CAPM to discount lost profits. ${ }^{112}$ Risky projects with uncertain profits are like risky securities: their unique risk may be diversified away, but "[t]he higher the [nondiversifiable] risk, the greater the expected return that will be required by an investor/firm." ${ }^{113}$ Thus, when a project fails because a defendant breaches, "it is necessary to compute the risk associated with these lost profits and appropriately adjust the discount rate in order to neither over nor undercompensate the plaintiff."114 The CAPM measures the relationship between nondiversifiable risk and return and thus can be adjusted for use in measuring the lost profits of a particular project. By replacing the market rate $(\mathrm{Rm})$ with the weighted average cost of capital of the injured party and calculating a beta that measures the correlation between the lost-profit and total-profit returns, the CAPM can generate the appropriate discount rate. ${ }^{\mathbf{1 1 5}}$

compensation for taking on this increased risk, and compensation will come from a higher required return from the risky asset.

${ }_{112}$ See Meyer, Fitzgerald, and Moini, $4 \mathrm{~J}$ Legal Econ at 35-38 (cited in note 57).

113 Id at 39.

114 Id at 38-39.

115 Meyer, Fitzgerald, and Moini add other refinements to their model, which results in the following formula:

$$
k_{r}=k_{r f}+\beta\left(k_{\mathrm{a}}-k_{\mathrm{rf}}\right)
$$

where:

$k_{r}=$ the appropriate discount rate for the lost profits,

$k_{f f}=$ the aftertax, risk-free interest rate on the appropriate United States Treasury obligation,

$\mathrm{k}_{\mathrm{a}}=$ the plaintiff's aftertax weighted average cost of capital,

and

$\beta=r_{l p, r}\left(S D_{l p} / S D_{r}\right)$

where

$r_{\mathrm{lp}, \mathrm{r}}=$ the correlation between the expected returns of the lost profits and the expect ed returns of the firm's total profits,

$\mathrm{SD}_{\mathrm{lp}}=$ the standard deviation of the returns on the expected lost profits, and

$\mathrm{SD}_{\mathrm{f}}=$ the standard deviation of the returns on the firm's lost profits.

$4 \mathrm{~J}$ Legal Econ at 36 (cited in note 57). As this formula vividly demonstrates, the financial analysis underlying this approach is extremely complex. Indeed, it is probably too complex for use by most courts. 
Although theoretically the most sound and precise, this approach fails as a default rule for a couple of practical reasons. First, the CAPM is a disputed theory in finance. One recent empirical study ${ }^{116}$ found no relationship between historical betas and returns in the CAPM model, concluding that "[i]n a nutshell, market $\beta$ seems to have no role in explaining the average returns on NYSE, AMEX, and NASDAQ stocks for 1963-1990."117 Thus, the very foundation of the CAPM - that it can measure, against the backdrop of the general market, the nondiversifiable risk of an asset and provide for that risk in the expected return-is questionable. Accordingly, the use of this model to discount future profits is also questionable. ${ }^{118}$

Second, application of this method is an administrative nightmare. Not only does it require a calculation of the cost of capital, it also requires more difficult calculations to conjure up a firm's beta. ${ }^{119}$ This approach involves interlocking levels of financial theory that compound the confusion of the fact finder and allow more variation in the experts' results. It is simply too complicated and too expensive, and is perhaps the paradigmatic reason why the gap between the world of law and world of finance still remains broad and deep.

\section{ENDING THE Legal LOTTERY: THE FIXXD-RATE RULE}

\section{A. Implementing the Fixed-Rate Rule}

The review of case law and the expert methodologies leads to a simple conclusion: neither triers of fact nor experts are well positioned to choose discount rates in contract disputes between commercial parties. The present value of a damage award, and

${ }^{115}$ See generally Eugene F. Fama and Kenneth R. French, The Cross-Section of Expected Stock Returns, 47 J Fin 427 (1992).

117 Id at 445. Fama and French also conclude that "our tests do not support the central prediction of the SLB model [CAPM], that average stock returns are positively related to market $\beta . "$ Id at 449.

118 Note also that experts often use the CAPM to measure the cost-of-equity component in the cost-of-capital approach. See Van Horne, Financial Management at 235 (cited in note 62) (using CAPM to calculate the cost of equity capital); Michel and Shaked, $19 \mathrm{~J}$ Bus Fin \& Acct at 458 (cited in note 57) (same). The weaknesses of the CAPM thus exacerbate the weaknesses of the WACC methodology.

"19 Betas for particular projects are notoriously difficult to figure out. The difficulty lies not in applying basic statistical formulae, but in digging up the data on the firm's total-profit standard deviation and lost-profit deviation and then finding the covariance between these data. Meyer, Fitzgerald, and Moini present a hypothetical example without going through this statistical labyrinth and fail to apply this formula to a real situation. 4 $J$ Legal Econ at 35-38 (cited in note 57). 
consequently the selection of a discount rate, depends on a finding of fact by the judge or jury. Experts, however, govern the courtroom with alluring rationales and finely tuned formulae. The selection of discount rates has moved out of the bounds of the law, into disputed areas of social science and beyond the understanding of most of the key parties involved. Indeed, one court has warned that discount-rate determinations should not be allowed to convert the courtroom into a "graduate seminar on economic forecasting," dictability and intelligible arguments have yielded to linear regression analyses and risk evaluation almost without a second thought.

Without the experts, however, courts cannot employ the complex methods reviewed above. Most judges and juries have neither the time nor the capacity to make informed choices of discount rates. Whereas the proposed finance methodologies at least take a structured approach to developing the proper discount rate, prevailing decisional law reveals little structure and too much inconsistency. The discretionary discount-rate regime has produced random results that aggravate the harm to injured commercial parties. Millions of dollars ride on decisions that judges and juries are not well suited to make.

Ultimately, the parties themselves should choose the appropriate discount rate or contractually define the parameters for making this choice. To avoid the legal lottery, commercial parties and fact finders must recognize that "in contract the damages payable should be set by agreement and not by any abstract principles of justice, however pleasing and symmetrical they might appear to judges." ${ }^{212}$ Accordingly, most would agree that "[t]he best approach is to state with precision the present value formula that you wish to use when drafting a contract."122 Indeed, the Restatement (Second) of Property suggests that, in lease disputes, courts recognize a liquidated-damages clause as a fair and reasonable estimation of damages only when the clause

${ }^{120}$ Doca v Marina Mercante Nicaraguense, S.A., 634 F2d 30, 39 (2d Cir 1980).

${ }^{221}$ Richard A. Epstein, Beyond Foreseeability: Consequential Damages in the Law of Contract, $18 \mathrm{~J}$ Legal Stud 105, 108 (1989). Epstein also notes that for remedial purposes, "[d]amage rules are no different from any other terms of a contract. They should be understood solely as default provisions subject to variation by contract. The operative rules should be chosen by the parties for their own purposes, not by the law for its purposes." Id.

${ }^{122}$ Cuff, Present Value, LA Lawyer at 26 (cited in note 58). 
includes a process for discounting. ${ }^{123}$ Good drafting can end the legal lottery before it begins.

But where contracts are silent, the legal system must fill the gaps and provide a default rule that will resolve the discount dilemma. This duty is complicated, however, and courts (perhaps understandably) have failed to dispatch it adequately. By putting forth varying, discretionary discount rates, courts have subjected commercial parties to unnecessary expense and uncertainty. A clear and simple default rule, however, could eliminate the legal lottery even for those parties who fail to resolve the discount dilemma in their contracts.

Courts should adopt a fixed rate, or a rate pegged to an easily identifiable market measure, as the default rule for selecting discount rates. For example, a fact finder could quickly and easily select a rate pegged to the investment-grade corporate-bond index published by the Wall Street Journal on the date of breach. ${ }^{124}$ Courts would then achieve certainty and clarity at lower cost. ${ }^{125}$

The medium-quality corporate-bond index probably is the appropriate market peg for the fixed-rate regime. ${ }^{126}$ This rate

${ }^{123}$ Restatement (Second) of Property, Landlord and Tenant \& 12.1 comment k (1977). At least two jurisdictions have implemented this rule. See Walter Implement, Inc. $v$ Focht, 42 Wash App 104, 709 P2d 1215, 1219 (1985), quoting United Leasing \& Financial Services, Inc. v R.F. Optical, Inc., 103 Wis 2d 488, 309 NW2d 23, 27 (Wis App 1981) ("Discounting has been recognized as the second operative element of a fair liquidated damages clause.").

124 Medium-quality corporate bonds are bonds rated by Moody's Investment Services as Baa or by Standard \& Poor's as BBB. They represent the lowest form of investmentgrade bonds-those bonds in which commercial banking institutions can invest as regulated by law. See Madura, Financial Markets at 85 (cited in note 108). The Wall Street Journal publishes a daily floating index of corporate rates compiled by Merrill Lynch. This index includes a listing for medium-quality corporate bonds. For example, on January 3, 1996, the medium-quality corporate bonds of durations less than ten years were earning 6.23 percent and the same bonds of durations ten years or more were earning 7.31 percent. Wall St J C20 (Jan 3, 1996).

${ }^{125}$ In practice, judges should defer to this fixed rate when they act as fact finders in discount-rate determinations. Similarly, when juries act as the fact finders, judges should instruct the jury to apply the fixed rate. Accordingly, the fixed-rate regime could be judicially implemented as the appropriate default rule. Of course, judicial implementation of the fixed-rate default rule is only an interim solution; ultimately, state commercial codes should incorporate the fixed-rate regime to convert what is now a finding of fact into a question of law.

${ }^{126}$ Some legal theorists argue that "courts should concern themselves not so much with the substance of the legal rule as with its certainty and predictability." Richard Craswell, Contract Remedies, Renegotiation, and the Theory of Efficient Breach, $61 \mathrm{~S}$ Cal L Rev 629, 632 (1988). Accordingly, it does not matter what market peg the courts pick, so long as they consistently defer to that rate in contract disputes. This Comment, however, will try to do more and justify the investment-grade rate as the most appropriate fixed 
accords with the general standard that, to properly compensate an injured party, discounting should reflect the rate of return at which the party can invest the damage award. ${ }^{127}$ The corporatebond rate is a compromise between the returns generated by riskless government securities and the less predictable stock market. ${ }^{128}$

Riskless government securities present too low a rate of return for corporate entities. Although individuals may be held to a low level of investment savvy when investing damage awards, ${ }^{129}$ corporate entities can be expected to exercise considerably greater prowess. Given their mandate to maximize shareholder wealth, corporate entities will likely use their financial and managerial expertise to attain returns greater than those available from low-risk government securities.

At the other end of the spectrum, the stock market, while boasting much higher rates of return, ${ }^{130}$ is also not the appropriate market peg. Historical rates of stock market returns do not necessarily predict the future, and thus cannot serve as an accurate market peg. The stock market is subject to daily and yearly variations that spell bust for some and boon for others. These variations are formally unpredictable and thus the rate of return is unknown in advance. ${ }^{131}$ The plaintiff's rate of invest-

rate.

${ }^{127}$ See text accompanying notes 21-24.

${ }^{123}$ In the 1980s, the Standard \& Poor's 500 earned an average annual return of 17.5 percent while Treasury Bills earned an average annual return of 8.9 percent. Long-term corporate bonds earned 13 percent, falling roughly midway between the stock market and risk-free securities. See Peter Lynch, Beating the Street 17 (Simon \& Schuster 1994).

${ }^{129}$ The Supreme Court, in Kelly, 241 US at 490, held that courts should not hold injured tort victims to a high level of investment prowess:

It may be that such [high] rates are not obtainable upon investments on safe securities, at least without the exercise of financial experience and skill in the administration of the fund; and it is evident that the compensation should be awarded upon a basis that does not call upon the beneficiaries to exercise such skill, for where this is necessarily employed the interest return is in part earned by the investor rather than by the investment.

Corporations, however, are built around maximizing the "financial experience" of management, and thus should be called upon to exercise this skill.

${ }^{130}$ Peter Lynch, one of the most successful mutual fund managers in history, remarks, "[b]y sticking with stocks all the time, the odds are six to one in our favor that we'll do better than the people who stick with bonds." Lynch, Beating the Street at 16 (cited in note 128). Lynch also notes that over the years $1926-89$, "a $\$ 100,000$ investment in longterm government bonds would now be worth $\$ 1.6$ million whereas the same amount invested in the S\&P 500 would be worth $\$ 25.5$ million." Id.

${ }^{131}$ According to the semi-strong form of the Efficient Capital Markets Hypothesis, 
ment should not be pegged to such an uncertain measure of financial success. ${ }^{132}$

Medium-grade corporate bonds provide a compromise. They generate a return greater than riskless securities and high-quality corporate debt, but are still sanctioned as stable investments. ${ }^{133}$ Moreover, these bonds are debt instruments, and thus, unlike stocks, their rate of return is generally fixed for the period of investment. ${ }^{134}$ By combining the financial expertise of a corporation with the need for certainty, the medium-grade bond rate emerges as the best peg for the fixed default rate.

\section{B. Justifying the Fixed-Rate Rule}

Before a court chooses this market peg, however, it must first face a more fundamental question: why adopt a fixed rate at all? A new legal rule must justify itself as an expansion and not a contraction of social welfare; in other words, the benefits of the new rule to both the parties and society must exceed its attendant costs. Ultimately an empirical question, cost-benefit analysis

security price movements quickly internalize all public information and engage in a random walk, or unpatterned changes in price. Thus, "one cannot use past security prices to predict future prices in such a way as to profit on average." Van Horne, Financial Management at 51 (cited in note 62). At least one portfolio manager, however, believes that stock investments still generate comparatively better returns than other financial investments. See Lynch, Beating the Street at 15-16 (cited in note 128) ("[S]ooner or later, a portfolio of stocks or stock mutual funds will turn out to be a lot more valuable than a portfolio of bonds or CD's or money-market funds.").

132 One could argue that if judgment is handed down, on average, two years after breach, the fact finder should use the injured party's aggregate real rate of return on investments for those two years to discount the lost profits for those same years. But this approach replicates many of the problems of the discretionary regime. First, expensive experts will need to define the parameters of a company's "aggregate rate of return" and then will have to conjure up the rate from complicated financial and accounting data. Moreover, parties will not know what rate will apply for those two years until the experts battle before the fact finder and thus will have to bear the costs of an uncertain rate. Finally, the fact finder must still select the appropriate rate for the remaining term of the contract, and thus the historical rate can be only a partial solution at best. It would seem better to avoid all this expense and uncertainty by fixing the rate at the date of breach.

${ }^{133}$ One investment-ratings service described medium-quality corporate bonds as "neither highly protected nor poorly secured . . . . Such bonds lack outstanding investment characteristics and in fact have speculative characteristics as well." Corporate Bond RatingsExplanation and Key, Moody's Bond Record 2, 3 (Dec 1995). Thus, these types of bonds represent a median type of investment yield that an injured corporate party could expect to enjoy.

134 Courts can roughly divide the universe of broken contracts into long-term contracts (greater than ten years) and short-term contracts (less than ten years). This division accords with the division of medium-quality bonds in the Wall Street Journal index. Courts can then lift the appropriate discount rate from the bond index based on the remaining life of the contract. 
can still draw from common-sense observations to reach a plausible conclusion. In this case, parties and society as a whole would get more for their money under a fixed standard than they do under the discretionary system now in place.

\section{Benefits of the fixed rate.}

First, a move to a fixed rate does not represent any quantum leap and will not upset party expectations. In tort law, courts basically defer to the risk-free rate when discounting lost future earnings ${ }^{135}$ and some states have even fixed the rate by statute. ${ }^{136}$ Moreover, at least one commentator has advocated the use of a fixed rate in "cramdowns" in bankruptcy reorganizations. ${ }^{137}$ In the contract setting, one court, in a dispute over an involuntary conversion of a mining lease, used a rate fixed by the Bureau of Land Management in its appraisal guide to discount the value of the lease. ${ }^{138}$ Given these incremental movements toward a fixed-rate regime, and the great expense and uncertainty parties face in the prevailing discretionary regime, a court adopting a fixed rate would be neither a lonely pioneer nor a bumbling fool. Rather, it would simply be extending a sensible methodology to an area of the law crying out for reform. ${ }^{139}$

Second, fixing the discount rate "reduces the associated uncertainty and, therefore, the costs of administering the remedial provisions." 140 A fixed rate such as the investment-grade bond rate merely requires the fact finder to open the Wall Street Journal and read a simple chart. ${ }^{141}$ Fact finders could dispose of ex-

135 See Meyer, Fitzgerald, and Moini, $4 \mathrm{~J}$ Legal Econ at 28 (cited in note 57) (noting that in lost-earning cases, "courts have treated future earnings as basically risk free"); Richard A. Posner, Law and the Theory of Finance: Some Intersections, 54 Geo Wash L Rev 159, 161 (1986) (noting that in compensating for lost future earnings, "[t]he tendency is to use a riskless interest rate in discounting lost future earnings to present value").

${ }^{136}$ See note 37. Indeed, some expert commentators have counseled other experts to use the "prevailing [risk-free] investment rate" in discounting tort losses because this rate "greatly simplifies the entire analysis by eliminating the interest rate forecasting process, the results of which tend to be a point of controversy in cases of alleged economic losses." Ledford and Zocco, 36 Fed'n Ins \& Corp Couns $Q$ at 39-40 (cited in note 5).

137 See Frankel, Comment, 2 U Chi L Sch Roundtable at 644 (cited in note 86).

${ }_{138}$ See Whitney Benefits, Inc. $v$ United States, $18 \mathrm{Cl}$ Ct 394, 412-13 (1989).

139 At least one expert commentator appears to advise other experts to adopt this "functional approach" to selecting a discount rate. See Blair, 8 Franchise L J at 23 (cited in note 4) ("To avoid the appearance of selecting an interest rate arbitrarily, one may use an average or index rate. For example, Barron's 'Best Grade' and 'Interim Grade' bond yields provide an average rate on bonds of comparable quality.").

140 See Epstein, $18 \mathrm{~J}$ Legal Stud at 118 (cited in note 121).

14 In Binghamton Masonic Temple, Inc. $v$ City of Binghamton, the court basically fol- 
perts and their fancy formulae, saving incalculable time and expense. ${ }^{142}$ Such ease of administration would also lighten the decisional burdens of judges, allowing them to focus on matters of contract law that they are specifically trained to examine. In this way, a fixed rate would benefit society by decreasing deadweight litigation costs and magnifying the comparative advantage of the courts.

Third, a fixed rate would reduce the direct litigation costs of the disputants. Parties would spend less on experts by avoiding the long and expensive financial analysis underlying most discount-rate methodologies. ${ }^{143}$ Moreover, legal fees may lighten as expert preparation and testimony become unnecessary. Accordingly, lawyers could focus more on crafting legal arguments (something they are trained to do), and less on manipulating financial analysis (something most would have to learn to do). The parties would pay less for a better product.

Fourth, the fixed rate is a clear and predictable default rule. It provides a fixed starting point around which parties may contract if they deem it unsatisfactory. ${ }^{144}$ Indeed, it may lower the cost of contracting by setting a baseline for bargaining. Thus, contract law should adopt this simple rule and allow contract parties to invent alternatives to meet their particular needs.

Fifth, the fixed-rate rule would allow parties to better insure against the cost of breach in the substantive terms of their contracts. Some parties might not bargain around the default rule but instead use it as a baseline to price their contracts ex ante. Most contracts contain some kind of premium for the expected loss from breach. ${ }^{145}$ Under the discretionary discount regime,

lowed this approach in a breach-of-contract dispute, although it deferred to the risk-free rate instead of the corporate-bond rate. 158 Misc $2 d$ 916, 602 NYS2d 310, 313 (NY Sup Ct 1993). The court found that the risk-free rate of United States Treasury bills should be used to discount payments from a broken loan agreement because this rate "represents a safe and ascertainable rate of return available for a plaintiff's financial recovery." Id. The court then used the New York Times financial pages to find the rate for fifteen-year United States Treasury bills and used that rate to discount the lost income from the broken loan agreement. Id.

${ }_{142}$ Of course, experts probably will still have a say in the aggregate calculation of lost profits, where a fixed rule would make no sense. But experts, parties, and fact finders alike will not need to spend the additional time and energy on choosing the appropriate discount rate, and that in itself is a benefit.

${ }^{14}$ For a discussion of how complicated this analysis can be, see notes 68 and 75 .

14 See Craswell, $61 \mathrm{~S} \mathrm{Cal} \mathrm{L} \mathrm{Rev} \mathrm{at} \mathrm{632-33} \mathrm{(cited} \mathrm{in} \mathrm{note} \mathrm{126)} \mathrm{(noting} \mathrm{the} \mathrm{effects} \mathrm{of}$ remedial legal rules on contract negotiations).

145 Id at 640-42 (discussing how parties include damage considerations when negotiating price terms). 
parties must make rough and arbitrary estimates of how to account for this indeterminable liability in the price of the contract. The discretionary regime may also increase transaction costs, as parties have more to haggle over when pricing the contract. A fixed-rate regime would provide parties with more information about their potential liability, leaving the parties to better set their breach premiums, as well as potentially facilitating the initial contract negotiations. Accordingly, a fixed rate would allow parties to better account for the expected value of loss ex ante.

Finally, a fixed discount rate might bring the parties closer together in settlement. Uncertainty often drives the litigation decision. ${ }^{146}$ Under the traditional economic theory of settlement, ${ }^{147}$ parties subjectively evaluate the expected benefits of going to trial and compare the benefits to their expected costs. Parties then base their settlement offers on these evaluations, and, under this model, parties will litigate if the plaintiff's minimum demand exceeds the defendant's maximum offer. A discretionary discount rate swells the uncertainty that feeds the litigation decision, allowing parties more room to diverge in their subjective evaluations, and thus increasing the potential for a bargaining failure. ${ }^{148}$

A fixed rate, however, would mitigate these unintended consequences. Fixing the discount rate would chip away at the uncertainty faced by disputants, bringing both parties one step closer to full information and thus one step closer to settlement. ${ }^{149}$ Thus, a fixed discount rate would provide in settlement some of the same benefits it offers in litigation: it is administra-

${ }^{146}$ See Geoffrey P. Miller, Some Agency Problems in Settlement, 16 J Legal Stud 189, 192 (1987) ("The existence of litigation is explained primarily by the uncertainty associated with a lawsuit. Litigation occurs because the parties differ in their estimates of either the probability that plaintiff will prevail in the lawsuit, or the amount of the recovery if plaintiff does prevail, or both.").

147 See generally Richard A. Posner, Economic Analysis of Law § 21.5 at 554-60 (Little, Brown 4th ed 1992); Richard A. Posner, An Economic Approach to Legal Procedure and Judicial Administration, $2 \mathrm{~J}$ Legal Stud 399, 417-20 (1973).

148 Indeed, Judge Posner himself recognizes the problems of a discretionary discount rate. See Posner, Economic Analysis of Law $\S 21.5$ at 556 (cited in note 148) (explaining that parties may evaluate stakes differently if "the parties have different rates at which they discount a future to a present value, which will cause their [expected judgments] to diverge").

${ }_{149}$ In a discretionary regime, parties waste time and energy bargaining over the appropriate discount rate, increasing the probability of a breakdown in the bargaining process. See Miller, $16 \mathrm{~J}$ Legal Stud at 193 (cited in note 146), noting that "[t]he existence of a positive settlement range is a necessary but not a sufficient condition for settlement. Even if the settlement range is positive ... the parties may fail to settle their dispute because of a breakdown in the bargaining process." 
ble, it is clear from the outset, and it saves the time and money of figuring out a proper discount rate. Thus, from contract formation to settlement or litigation, a fixed-rate rule offers substantial opportunities for lowering transaction and bargaining costs.

\section{Costs of the fixed rate.}

First, like any strict rule, a fixed-rate rule may be systematically over- or underinclusive. Parties who earn rates of return higher than the fixed rate are overcompensated; parties who earn lesser returns are undercompensated. This distortion in compensation might upset the fundamental goal of contract damages-to give the injured party the benefit of his bargain, no more and no less. Courts might therefore prefer to disregard a fixed-rate rule and to continue to tailor the discount rate to the particulars of the dispute, thereby achieving (in theory if not in fact) finely tuned compensation.

This argument, however, does not dispose of the fixed discount rate. For one thing, it is not intuitively obvious whether this rule, like the discretionary regime, over- or undercompensates. Contract plaintiffs are free to do whatever they wish with the funds that they receive as damages. They may invest in stocks, bonds, derivatives, business operations, or otherwise, and each investment carries its own potential return. Thus, in the ex ante position, it is not evident what investment rate the plaintiff will earn, no matter what methodology experts employ to divine a potential rate. ${ }^{150}$ Further, exact compensation in every case is an illusory goal. The Supreme Court has recognized that discounting is "rough and ready" approximation" ${ }^{151}$ and counseled against a search for "delusive exactness." ply an imperfect process no matter how it is done. A marketpegged fixed rate may be just as accurate on average as the methodologies currently employed by financial experts.

Second, the marginal benefits of the discretionary discount methodologies in minimizing the risks of over- and undercompensation probably do not exceed the marginal costs of those

${ }_{150}$ See Bridgkort Racquet Club, Inc. $v$ University Bank, 85 Wis 2d 706, 271 NW2d 165, 170 n 9 (Wis App 1978) ("There is nothing sacred about the $7 \%$ interest rate return. It may be that Bridgkort's choice might be to invest the money at a lower return rate. Or it may be able to obtain even a higher rate of return. Obviously, precision in present value computation is impossible.").

ist See Jones \& Laughlin Steel, 462 US at 546.

152 Id at 552. 
methodologies. Because all discounting is admittedly imperfect, the popular finance formulae that experts employ to "scientifically" reduce the risk of miscompensation ${ }^{153}$ will likely never achieve that goal exactly. ${ }^{154}$ The costs, however, are real and paid by the parties. Accordingly, one must ask whether the marginal benefits of a potentially more accurate, undisclosed compensation formula justify the quantifiable marginal costs that it creates. This regime must then be compared to the "rough and ready" fixed-rate rule that captures a slew of real benefits ${ }^{155}$ while potentially expanding the variance of the miscompensation risk. This Comment takes a strong stand in favor of the tangible benefits and potential costs of a fixed rate over the potential benefits and tangible costs of a discretionary system.

Finally, the fixed rate is a default rule for contracts, and parties can contract around it if they deem it under- or overcompensatory. Indeed, contractual provisions probably are the best approach because they allow the parties to tailor the legal rule to the specifics of their relationship while avoiding the courtroom. A home-grown remedy provides the certainty of a fixed-rate rule, avoids unnecessary litigation, and spells out party expectations in advance. So even if this default rule does not exactly replicate what parties would choose, a noncompensatory, fixed discount rate may ultimately be the proper rule of compulsion that alerts parties to the perils of failing to address discounting on their own.

Another criticism of the fixed rate might be that it encourages inefficient breaches. The theory of efficient breach states that the expectation measure of damages forces breaching parties to internalize the plaintiff's full cost of breach. ${ }^{156}$ Thus, parties breach only when the total cost of breach is less than the total benefit, thereby maximizing social welfare as goods flow to the highest-valued user. Remedies that are noncompensatory distort breaching decisions, drive a wedge between the social and private optimum, and cause parties to breach too little or too much. ${ }^{157}$

${ }_{153}$ Even experts agree that "imperfect foresight regarding the future structure of interest rates means that the exact earning ability of the corpus of an award cannot be determined with certainty." Ledford and Zocco, 36 Fed'n Ins \& Corp Couns Q at 28 (cited in note 5).

154 Indeed, no one has engaged in an empirical study of the correlation between discount rates and actual rates of returns enjoyed by injured parties after awards are made.

${ }_{155}$ For a discussion of these benefits, see Section III.B.1.

156 See generally Robert Cooter and Thomas Ulen, Law and Economics 289-92 (Harper Collins 1988); Posner, Economic Analysis of Law $\$ 4.8$ at 117-26 (cited in note 147).

${ }^{157}$ See Craswell, $61 \mathrm{~S}$ Cal L Rev at 634-35 (cited in note 126), noting 
A noncompensatory, fixed discount rate could thus hurt commercial parties and society by encouraging inefficient breaches.

This efficient breach argument, however, is unpersuasive. First, as the discussion above illustrates, it is not clear whether any rate, including a fixed rate, would over- or undercompensate in practice. ${ }^{158}$ Because discounting is inherently imperfect, courts rarely achieve "perfect compensation." Accordingly, inefficient breach may occur no matter what discount regime captures the court's attention. This fact, however, does not deter courts from discounting future awards to present value now and should not deter them from adopting the fixed-rate approach in the future. ${ }^{159}$ Any "rough and ready" damage award simply runs the risk that parties may breach too much or too little. A fixed rate, however, carries the same risk at lower cost.

Furthermore, parties can correct an inefficient breach "problem" through ex ante and ex post negotiations. If the default rule is noncompensatory, parties can easily construct efficient breach incentives with a properly discounted liquidated-damages provision that properly compensates the injured party. Alternatively, even without a liquidated-damages provision, parties may renegotiate upon breach, striking a new bargain that is satisfactory to all involved. ${ }^{160}$ Indeed, a fixed rate may reduce transaction costs, fixing a baseline for bargaining over the discounting process or allowing parties to focus on more important issues. With

If a breaching seller must pay damages equal to the value of the goods to the first buyer, the seller will find it profitable to breach the contract only if the second buyer is willing to pay more than that amount. ... [S]maller damage awards could make it more profitable for the seller to breach even when the second buyer is not willing to pay more then the goods are worth to the first buyer, while larger awards could make it unprofitable to breach even when the second buyer is willing to pay more. Thus, only a perfectly compensatory remedy appeared to give the seller the right incentives in deciding whether or not to breach.

258 See text accompanying notes 150-55.

139 Even damages that do not require discounting "often fall short of a truly compensatory measure due to the exclusion of such items as attorneys' fees, unmeasurable subjective losses, and 'unforeseeable' damages." Craswell, 61 S Cal L Rev at 637 (cited in note 126). See also John A. Sebert, Jr., Punitive and Nonpecuniary Damages in Actions Based Upon Contract: Toward Achieving the Objective of Full Compensation, 33 UCLA L Rev 1565, 1571-84 (1986) (detailing how expectation measures fall short of the full compensation ideal). Therefore, the critical assumption of efficient-breach theory-that compensation is perfect because it captures all private and social costs-is probably inaccurate under any discount-rate regime. See generally Daniel Friedmann, The Efficient Breach Fallacy, $18 \mathrm{~J}$ Legal Stud 1 (1989).

${ }_{160}$ See Craswell, $61 \mathrm{~S}$ Cal L Rev at 635-36 (cited in note 126) (explaining the renegotiation option). 
reduced transaction costs, renegotiation is more likely, and a noncompensatory remedy matters less. ${ }^{161}$ Thus, claims of inefficient breach should not stop a court from adopting the fixed-rate approach.

Another critique of the fixed-rate regime might be that, as a default rule, it imposes unnecessary drafting costs on parties. Because it is not tailored to the particular situation, the fixedrate rule may force parties to draft present-value clauses that fit their unique expectations. If these costs are higher than those of allowing a court to determine the rate, then changing the current rule may impose costs that parties would like to avoid.

This point should not persuade a court to reject the fixedrate regime. An investment in the certainty of a contractual provision that sets the discount rate or provides for a selection methodology probably is more cost-effective than letting the courts decide the rate at their discretion. Parties in specific industries could standardize their present value formulae, enabling them to spread the initial outlay of determining the proper methodology across a number of transactions. Litigation, however, generates a unique outcome for each case, so expert and lawyer expenditures are necessarily duplicative. Moreover, a bargained-for damages clause could fix the discount rate if breach occurred, and thus the costs of negotiation would at least yield the benefits of certainty. An investment in litigation costs, however, buys the parties no more than a ticket to the legal lottery, producing only an uncertain return. Accordingly, a fixed rule that encourages damage provisions probably does more good than harm.

A final critique might be that commercial parties would prefer the discretionary regime because the rampant uncertainty in damage awards deters breach and keeps the parties in line. Because the discount rate is uncertain ex ante under the discretionary regime, parties may not be able to properly evaluate the costs and benefits of breach. Given an unclear and expensive evaluation process, commercial parties may opt for the more definite path of simply performing the contract.

Uncertainty, however, cuts both ways: perhaps it discourages breach, but it could just as easily encourage breach by distorting the party's evaluation of its costs and benefits. ${ }^{162}$ Just as a par-

162 Just as uncertainty generates asymmetrical evaluation and drives parties further apart in the litigation model, see text accompanying notes $146-49$, it may similarly distort predictions when deciding to breach or not. 
ty might overestimate its potential liability from breach by predicting that the court will choose an unfavorable discount rate, so it might underestimate its potential liability by predicting that the court will choose a favorable one. Thus, the discretionary discount regime may in fact encourage breach, thereby erasing the deterrence value posited above.

Ultimately, the discretionary discount rate's deterrence value, if any, should pale in comparison to its costs. The total cost of experts, litigation, and uncertainty casts a long shadow over the entire contracting process. Parties are forced to incur these costs because the law-and not business-has chosen a discretionary regime. The fixed rate, however, cures many of the ills of the discretionary regime, adding new benefits and imposing fewer costs. Faced with "the full range of prospects and perils that the contract itself addresses at formation," ${ }^{2163}$ most parties would opt for a quick fix for the legal lottery.

\section{CONCLUSION}

A clear default rule should guide courts when they choose discount rates to calculate the present values of lost profits in commercial-contract disputes. The current discretionary regime has generated a confused jurisprudence, subjecting sophisticated commercial parties to a legal lottery in which expensive experts battle for unpredictable results. A discount rate pegged to an easily identifiable market index would eliminate the potential for expert bias, the excessive costs, and the unnecessary uncertainty that marks the discretionary regime. By adopting this "rough and ready" default rule for choosing discount rates, courts will make commercial parties better off and enhance social welfare. Indeed, by fixing the legal lottery, courts will finally abide by their commitment to clarity and certainty in contract law. 
